\title{
Agency, Identity, and the Great Crisis: a Veblenian Perspective
}

Mary V. Wrenn

Mary V. Wrenn is an associate professor at Weber State University. She is currently on leave and working in the UK as the Joan Robinson Research Fellow in Heterodox Economics at Girton College, University of Cambridge. This paper was presented at the annual meeting of the Association of Evolutionary Economics, January 6-8, 2012 in Chicago.

\footnotetext{
Abstract: Within neoliberalism, an individual's agency and identity are fundamentally different than at any other stage in human development. The argument set forth is that within neoliberalism, agency and identity are, respectively, falsified and fluid, which further supports the intensification of the neoliberal project. When studied through the Veblenian lens, the role played by the habituating tools of commodity fetishism, conspicuous consumption, and moral panics become clear, demonstrating that while fundamentally different, neoliberal agency and identity emerge from previously established habits of thought.
} 
Keywords: agency, identity, neoliberal, Veblen

JEL Classification Codes: B25, B52, N32

\section{Identity and Agency}

Identity is most easily understood using Davis's (2009) rubric $^{1}$ of three distinct, interrelated components: "personal identities," which are self-ascribed; "individual identities," which are otherassigned identities; and "social identities," which consist of voluntary self-identification with social groups, both formal and informal, with varying levels of commitment ${ }^{2}$ to each social group. Under Davis' rubric, individuals are self-reflective and interact with their surrounding institutional context. All individuals possess identity, and the overall identity of all individuals consists of these three essential pieces.

"Personal identity" is determined through self-reflection, consciousness, and evaluation of self. Personal identity is constructed through individual identity and social identity, but is not reducible to simply the sum of those two parts and not in proportionate measure. Rather, personal identity might be more correctly framed as the consequence of individual and social identity, in conjunction with the individual's agency and mental models.

The individual agent has no control over "individual identity." Individual identity is otherassigned by the surrounding institutional context and may be based on physical characteristics, such as gender, and social attributes, such as income class or identifications consisting of socially 
constructed meanings. Individual identity actively shapes personal identity through formal tools employed by the state such as "names, number assignments, biometric techniques" (Davis 2009) as well as through informal mechanisms which work to communicate any given culture's tacit metrics, for example, of attractiveness or intelligence. According to Davis, these other-assigned, individual identities are stable throughout time (2009). As Folbre (1994) describes, individual identity consists of inclusion into "given groups," while social identity consists of identification with "chosen groups"; whereby the individual agent does not have the choice of belonging or commitment to the former, but does to the latter.

Personal identity and individual identity do not seamlessly integrate; while harmony between the individual's awareness and aspirations of self and the institutionally defined self might exist, so does conflict and tension (Davis 2009). "Social identity" is selected by the individual purposefully to incorporate into her personal identity and assists the individual in negotiating between personal and individual identities (Davis 2009). The individual exercises agency and decides to which social groups/identities she wants to belong, as well as how committed she is to each respective social group. These social groups may represent cultural or counter-cultural ideals and may be based on any type of shared social norms. Social identity is thus the result of the individual agent's personal identity interacting with the surrounding institutional structure and the other-assigned, individual identity (Davis 2007). Social identity may also be characterized as representative of the individual agent's struggle to reconcile her personal identity and her other-assigned, individual identity; the larger the perceived incongruence, the more important social identity becomes to the individual agent. 
Agency is power - the power to act and the power to choose. Agency requires consciousness. Consciousness removes the deterministic conceptualization of the individual. The individual's internal evolution of consciousness - self-reference and evaluation - interacts and is as much a factor in the resultant action as is the historical path of the individual and her institutional context (Davis 2009). In order to exercise agency, the individual must possess the power of self-reference while recognizing - regardless of accuracy - social influences and her power to act and react to them (Davis 2003). Self-referential refers to the agent's ability to develop a perception of her own position and part of the surrounding structure. Under this conceptualization, agency is thus empowered to change structure as well as is conscribed by it. This of course, doesn't mean that selfreference and self-conception are automatic or authentic (Davis 2003). Indeed, the issue of nonauthentic self-reference fundamentally changes the character and consequence of this interactivity.

Interactive agency allows for mutual causation between institutions and agent. The interactive agency framework simultaneously recognizes the interdependence and independence of agent and institutions (Davis 2003). The individual is not overly socialized, nor a passive recipient of institutional information and pressure. Recognition of the ability of institutions to change and influence an individual's agency should not be stretched to the point of determinism. Agency depicted through the socially embedded conceptualization of the individual is not true agency if the individual is not imbued with the power to influence the surrounding structure in a truly interactive fashion.

Individuals might not recognize structure or the sway structure holds over their power to act. Rather, individuals may not register the influence and further may not recognize the fallibility of their perception of the surrounding structure. Individuals may indeed exercise agency while 
possessing the power of self-reflection, but those individuals are engaging agency that is not authentic when that self-reflection exists within institutional contexts which represent the veiled exercise of power - or agency - on behalf of others who are more powerfully positioned. As such, well-intentioned individuals may be accurately exercising self-referential behavior but within a fallacious frame of reference. The social meaning of an act in such a scenario does not parallel necessarily with the individual's intended meaning (Pratten 1993). Agency with the specific institutional context of neoliberalism requires erroneous authenticity to sustain it.

From this, the analysis of identity can be connected to the idea of agency; that an individual's choice in decision-making may rationally depend on her interest in maintaining continuity with her identity. This would appear to reinforce the idea that an individual's agency is determined by the degree to which she is self-referential, and therefore is on a fundamental level making choices that reflect the self-referential identity the individual has constructed or adapted.

\section{Authenticity of Agency and Incongruity of Identity}

Neoliberalism enshrines the free market as the one true path to progress and teaches through the socialization process that each individual should be accountable to herself. In so doing, each individual's responsibility to others and to the collective is eroded. Society is then comprised entirely and solely of self-interested, atomistic individuals seeking to forward their own agendas. The emphasis on individual accountability and responsibility naturally segues into the power of the individual acting alone. Within the neoliberal system, agents are not only taught the ethos of individual responsibility, but also that they are the drivers of destiny. Agency framed in this manner supports and thereby reinforces the structure of neoliberalism. 
There is authentic agency and then there is neoliberal agency. The former depends wholly on the ability of the individual to exercise authentic self-referential behavior (Davis 2003). The latter depends on the individual perceiving herself as authentically self-referential. Neoliberal agency constructs and instructs the superficially empowered individual and perpetuates the illusion of autonomous decision making. This is not to suggest that individuals become puppets to the institutions of neoliberalism - there most certainly remains genuine interaction between individuals and institutions and the economic agent is still able to exercise discretion and some authentic agency in her decisions. What is being suggested is that while the exercise of agency is itself authentic - the individual is empowered to interact with and change institutions - the character of agency within the neoliberal project is not.

The grand illusion of neoliberalism is the autonomy and freedom of the individual; that the individual is completely self-efficacious and thereby possesses free and uninhibited agency. As such, well-intentioned individuals may be accurately exercising self-referential behavior but within a fallacious frame of reference. There are thus two layers of the neoliberal economic system: the superficial layer in which the individual perceives herself to be situated and is accurately selfreferential and then the underlying layer in which corporations operate and attempt to sustain the former other, public face of neoliberalism. ${ }^{3}$

The face of neoliberalism, that part of the social structure of accumulation of which everyone is aware advocates for individual accountability, small government and a small welfare state, privatization, and de-regulation. In this layer of reality the individual possesses complete power and agency over decisions. The agent is completely self-referential within this superficial layer, and more importantly, perceives herself as authentically self-referential. Beneath the skin of 
neoliberalism presides the genuine institutional framework of neoliberalism. It is at this level - the political-corporate level - that true context, reality, and feasibility are constructed.

Agency within the specific institutional context of neoliberalism requires erroneous authenticity to sustain it, implementing tailored cultural mechanisms and artifacts to construct and support this self-referential, yet non-authentic agency. The key cultural mechanism is identity.

If the individual agent's personal identity is subordinated to her individual-neoliberal identity, then when her personal identity grows increasingly incongruent to her status in the polity and economic hierarchy, rejection of neoliberal individual identity appears inevitable. Individual identity within the historically specific institutional context of neoliberalism is predicated on financial success. Individual-neoliberal identities that are measured via financial success are manifest not only in class categories, but especially through their ordinal rankings: upper, middle, lower, or proxies for these ranks, such as "working" or the color of the collar that still clearly indicate rank in the ordinal hierarchy. The individual identities ascribed by the neoliberal context for those who have not achieved financial success or advance in ordinal class rank include epithets such as: "loser," "trailer trash," "ghetto," and "welfare queen" (George 2006).

With respect to individual-neoliberal identity, history does not matter. Under the enabling myth of equality of opportunity, all individuals, regardless of beginnings or background, are responsible for their own success or failure. In this bootstrap society, individual-neoliberal identity redirects and is not cast as other-assigned, but rather as self-determined. The more that the public views society as fully democratized and that advancement is based on merit, the less it recognizes the influence of heredity in neoliberal identification and rank, and the more demoralizing the 
inferior assigned identity is: "With a meritocratic free-for-all, falling short can become all the more painful" (George 2006).

\section{Commodities and Consumption}

The existence of the market economy is predicated on persistent commodification. Indeed, social life itself becomes subjected to the forces of commodification and consumption; individuals within the intensified neoliberal market are so detached from personal relationships that they must find a connection through commodities. Ideas that support the neoliberal project are objectified, reified, and commodified to the extent that they are no longer ideals but idols that are to be venerated, coveted, and protected. The commodification of these ideas serves as a self-referential identifying mechanism for the alienated individual. The individual feels socially connected to other individuals and the larger community through the shared fetishism of the objectified and commodified ideas of democracy, freedom, and independence - all of which construct identities and the superficial social context within which the individual perceives to be situated. These icons embody the power of the individual and need not support neoliberalism per se. Indeed, the commodification of freedom manifests itself in objects that support the system, such as products which feature the U.S. flag as well as objects which allow the individual to identify herself as part of the counter-culture vent, such as products which feature Che Guevara.

When the individual feels powerless, neoliberal commodification provides symbols of power, and the means by which that power is conspicuously displayed (Veblen 1899). Fetishized commodities, or "symbolic goods" help the individual define herself (Dolfsma 2004). Clothing, for example, is a mechanism of "symbolic display," of communicating the wearer's identity to the 
external world (Giddens 1979). The empowerment an individual draws through these mechanisms of identification does not necessarily detract from the operation of the neoliberal project; indeed the individual's perception of power and connection with others supports the neoliberal system to a point.

Commoditized identity is arbitrary, in that one may select an identity from a sort of vending machine of ideologies, ethnicities, or causes. Identity that has been constructed via commodities or commodified ideals is much more fluid than that of authentic self-referential identity; it is identity that has been purchased (O’Neill 1998). Even authentic identity is dynamic in the sense that it is an organic phenomenon that is adaptive and changes in sync with one's own evolution and/or development. When, however, the flow of identity is punctuated, changing in tandem with changing fashions and is therefore discontinuous in composition; it lacks authenticity (O’Neill 1998). Inauthentic or superficial identity is fragile. Once this fragile identity is fractured, the individual is forced to redefine her identity.

If an individual commits to a social identity, but that commitment is superficial and expressed mainly through commoditized symbols, then the individual's personal identity is as fragile and fluid as the commitment to that social identity. The more fluid, the more superficial the commitment to a social identity, the less able the individual is to "maintain a coherent, unified narrative or discourse about (herself)" (Davis 2009). The less unified the narrative, the more unstable the person, and the more likely that the individual will engage in identity politics or even violent expressions of identity politics.

\section{Morality and Demons}


During periods of social change or economic instability, it is helpful to have somewhere or someone at whom a finger might be pointed. Demonization of the "other" is a well-worn tradition in the United States (although certainly not created in the United States), where despite having left England in order to practice religious freedom, English colonists then conducted the Salem witch trials of the 1690s (Befu 1999). It is not enough, however to say that uncertainty breeds scapegoating. Demonization is specified scapegoating: it is a means by which individuals can feel better about themselves and take satisfaction in their own superiority (Befu 1999).

Within the neoliberal project, widespread social problems, such as unemployment, lack of access to medical services, economic insecurity, and housing insecurity are reframed as problems with an internal locus of control - failure is the result of an individual's personal failure, not a failure of the larger system (Prasch 2011). Despite neoliberalism's hyper-individualism, blame for failure can be externalized. In the 1980s, the spectre of young, single mothers and welfare queens haunted the conservatives of the Reagan-Thatcher era (McRobbie 1994); today, the Occupy movement demon "frighten(s) to death" Republican strategists.

The less control an individual has over her future, the more insecure her place, and the less empowered she feels to change her circumstance, the greater the fulcrum of stress that will eventually manifest as moral indignation, and perhaps later, moral panic. Moral indignation is a means of gaining a sense of control (Prasch 2011). Economic insecurity for both the middle class and working poor, especially during a period of uncertain employment, heightens moral indignation and sharpens it. The "American dream," unfulfilled, despite the promise of the payoff of hard work, is the petri dish of moral indignation (Young 2009). 
As Prasch points out, the invidious distinction of moral indignation becomes fashionable: "In a manner parallel to Thorstein Veblen's description of the spread of upper-class fashions, the social agenda of the upper class becomes society's social agenda” (2011; Veblen 1899).

One can become even more virtuous letting his reputation hinge on his righteousness, building his self out of invidious comparison to the morally weak. Since others' wickedness sets off the jewel of one's own virtue, and one's claim to virtue is at the core of his public identity, one may actually develop a stake in the existence of deviant others. (A. Cohen 1965, emphasis original)

Individuals are able to make invidious distinctions from other social groups through moral indignation against a particular social group. Individuals are also able to construct identity and connection to others through that moral indignation as a defining characteristic of one's self as well as demonstrating the individual's moral superiority (Young 2009).

Once hegemonic structures reach a crisis of critical mass, moral indignation may ramp up to a moral panic (Young 2009). A moral panic involves a spontaneous, unintended coordination of the mass media, politicians, and morally outraged groups. Moral panics that persist hold the potential for manifesting into identity politics, the outcome of which includes the possibilities ranging from legislative action to violence between social identity groups (S. Cohen 1972).

\section{Through the Veblenian Lens}


The perpetual state of crisis avoidance within the neoliberal project breeds insecurity and uncertainty. While individuals operate under the perception of complete autonomy and efficacy, the veiled locus of power resides in the deep political reach of the corporate sector. Falling short of the neoliberal markers of success leads individuals to find fulfillment in identities outside the economic sphere through social groups or causes.

The "invidious distinction" of Veblen's "conspicuous consumption" explains quite clearly the means by which individuals find agency and identity through commodities (1899). Regardless of how the individual identifies herself, the commodification conscribes identification to a superficial level, provides false empowerment to the individual, and actually supports the accumulative drive through the creation and sale of commodities. Likewise, individuals can assert self-perceived superiority through moral indignation over socially constructed demons. Moral indignation and its heightened stage of moral panic can be interpreted as a nativistic reaction - the resistance side of the Veblenian dichotomy - that attempts to press the brakes during periods of social change.

The coping mechanisms which serve as responses to the erosion of empowerment and failure to reach the ideals of neoliberal identity include old habits of thought recast in the current context. Indeed, it is through the Veblenian lens that we see consumption and moral indignation are simply new variations on old themes.

\section{Notes}

1. Davis's 2009 paper draws from the "sociological approach to identity" rather than psychology's "social identity theory," as he explains in Davis 2007. 
2. Use of the term "commitment" here is general and does not begin to address the complexity of the term as used by Sen. See for instance: Sen 2002.

3. Recalling Gidden's description of "deeply layered" structures, there most certainly exists the possibility of more than two layers within neoliberalism. For the present purpose, only the superficial and political-corporate layers will be examined.

\section{References}

Befu, Harumi. "Demonizing the Other." In Demonizing the Other: Antisemitism, Racism, and Xenophobia, edited by Robert S. Wistrich, pp. 17-30. Amsterdam: Hardwood Academic 1999.

Cohen , A.K. "The Sociology of the Deviant Act: Anomie Theory and Beyond." American Sociological Review 30 (1965): 5-14.

Cohen, Stanley. Folk Devils and Moral Panics. London: McGibbon and Kee, 1972.

Davis, John B. The Theory of the Individual in Economics: Identity and Value. London: Routledge, 2003.

—. "Akerlof and Kranton on Identity in Economics: Inverting the Analysis." Cambridge Journal of Economics 31 (2007): 349-362.——. "Identity and Individual Economic Agents: A Narrative Approach." Review of Social Economy 67, 1 (2009): 71-94.

Dolfsma, Wilfred. "Consuming Symbolic Goods: Identity and Commitment - Introduction." Review of Social Economy 62, 3 (2004): 275-276.

Folbre, Nancy. Who Pays for the Kids? London: Routledge, 1994. 
George, David. "Social Class and Social Identity." Review of Social Economy 64, 4 (2006): 429-445.

Giddens, Anthony. Central Problems in Social Theory: Action, Structure and Contradiction in Social Analysis, Berkeley: University of California Press, 1979.

McRobbie, Angela. "Folk Devils Fight Back.” New Left Review 203 (1994): 107-116.

O'Neill, John. The Market: Ethics, Knowledge and Politics. Economics as Social Theory Series. London: Routledge, 1998.

Prasch, Robert E. "Capitalism, Freedom and Democracy Reprised; or, Why Is the Liberalization of Capital Associated with the Increased Repression of Individuals?" Journal of Economic Issues 45, 2 (2011): 277-288.

Pratten, Stephen. "Structure, Agency and Marx's Analysis of the Labour Process." Review of Political Economy 5, 4 (1993): 403-426.

Sen, Amartya. "Goals, Commitment, and Identity." In Rationality and Freedom, edited by Amartya Sen, pp. 206-224. Cambridge, MA: Harvard University Press, 2002.

Veblen, T. B. The Theory of the Leisure Class. New York: Macmillan, 1899.

Young, Jock. "Moral Panic: Its Origins in Resistance, Ressentiment and the Translation of Fantasy into Reality.” British Journal of Criminology 49 (2009): 4-16. 